\title{
Imagine-making disciples in youth ministry ... that will make disciples
}

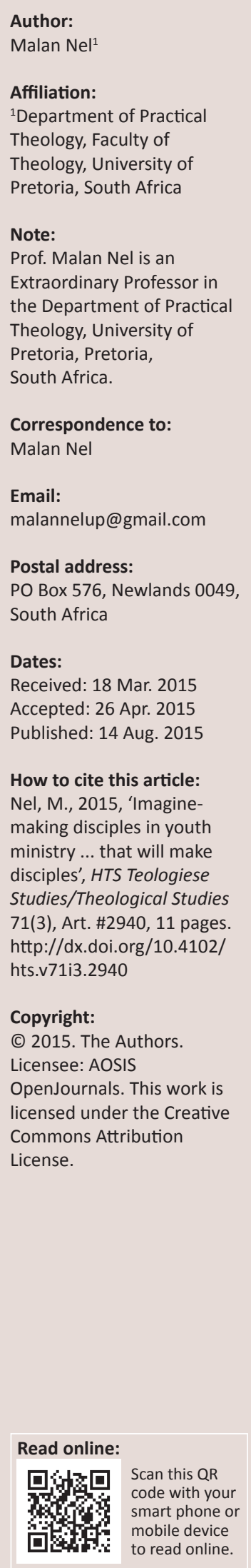

Discipling youth may be one of the 'missing links' in developing missional thinking and missional local churches. This is even more so where churches suffer from a very obvious estrangement among generations. This article draws on the most recent literature on developing missional churches. The departure point is the argument of a the New Testament scholar, who refers to the description of Matthew 28:16-20 as the manifesto of the church - a manifesto that lies on the same level of value as the Shema of Israel: 'Listen, o Israel, the Lord our God is the only One.' This manifesto wants to tell us how new and differently we have to think on how people come into the body and how people will stay in the body. Picking up on three of my theological premises this article will work with a research question: What kind of church will make disciples in youth ministry? It will also work towards theological suggestions on how to make disciples in youth ministry in such a way that young disciples will make disciples.

\section{Introduction}

I consider it a special honour to participate in the Festschrift for Christo van der Merwe. We have come a long way. In 1994 he participated in an Advanced Course for Gemeentebou that I offered. We became not only good friends but also later in his life I could be his external examiner for his $\mathrm{PhD}$ thesis in this subject field. Since then we have continued to work together and he helped in the offering of the same course for many other pastors in their programme for continuing theological training. My contribution in this article is indeed to honour him and to focus on a theme that is important in his thinking and approach. I purposefully focus on the youth. I am convinced that Christo believes with me, that if we do not transform local congregations into disciple youth we are, in a sense, labouring in vain.

God wants all of us to have life and life abundantly (cf. Jn 10:10b). This runs like a golden thread (core issue) through the whole of the Bible. The ministry of Jesus is in this regard only the fulfilment of what was God's purpose for humans all along. Life is a gift of God. This is the meaning of for example Psalm 127: 'Sons are a heritage from the Lord, children a reward from him' (New International Version [NIV]). God created (gave life) and continues to do so. However powerful evil is, it cannot 'produce' life (humans). God in Christ and by the hermeneutical work of the Spirit helps us to rediscover and re-interpret life. The Gospel of Matthew is full of his remarks: 'You have heard that it was said ... But I tell you ...' (cf. for example the many times in the Sermon on the Mount, Mt 5-7).

My port of entry in this article will be that we have missed and are missing the quality of the life we received. Our call to discipleship and the making of disciples is to get back the fullness of our lives. The journey of discipleship is one lifelong journey of rediscovering and recovering the fullness we may have missed.

My conviction after the many years in youth ministry and in youth ministry research and training is that we have missed this Kingdom-like perspective on salvation and life as such. For some or other reason (some quite understandably so) our understanding of salvation as decision-making rather than disciple-making has not done the job. It is misfiring and backfiring into our faces. Faith communities are paying the price. Shallow, even superficial, connections to the Christ and his body are falling apart in front of our eyes. So much so that, in spite of the many exceptions the 'church' is in trouble around the world.

In the article 'Inviting and initiating youth into a life of discipleship' (Nel 2009) I posed the following:

The research question/problem on which I want to reflect in this article is whether we have lost the radical nature of the faith community as disciples of Jesus and seekers of the Kingdom. Have we to follow 
Jesus into the mission field? (Cf. Easum 2001) If so, how should we invite and initiate youth into a life of discipleship? (p. 99)

Picking up on three theological premises in that article, namely:

- that children and adolescents are an integral part of the faith community

- that youth ministry is in essence done relationally and if and when at all possible by a parent or parents AND in the closest relation with 'the home'

- that discipling youth is about celebrating initiation, giving guidance on a road of fulfilment in life, and facilitating discernment on the journey.

This article will work towards theological suggestions on who will and how to transform faith communities into a movement where we make disciples in youth ministry - in such a way that young disciples will make disciples.

I will focus on three questions and dimensions in particular:

- how discipleship and discipling is dealt with in the socalled missional conversation

- what kind of 'people' are best suited to make disciples in youth ministry - being before doing

- what will we have to change in our Christian Education (teaching and learning) in order for youth ministry to reform and transform local faith communities into disciple-making movements?

\section{Discipleship and disciple-making in the missional conversation}

The literature that 'covers' this conversation is vast. I will not even attempt to be all-inclusive. After working through more than 100 publications on missional thinking in 2013 I still have only scratched the surface. There are some 118 references to disciples, discipleship and disciple-making in these publications. I can summarise the references here but refer to 21 of these authors in the bibliography below. Not all of them are considered to be formally part of the so-called missional conversation. Some 25 references were found in the more than 30 authors consulted in the field of youth ministry. I refer to four of them in the bibliography below.

There may be many reasons why we shy away from this central concept and metaphor of discipleship in the teachings of Jesus. Ogden (2003:39-56) in a chapter on 'The discipleship malaise' discerns eight factors that have contributed to 'the low estate of discipleship, to the church's failure to grow self-initiating, reproducing, fully devoted followers of Jesus' (2003:40):

1. 'pastors have been diverted from their primary calling to 'equip the saints for the work of ministry' (p. 40)

2. 'we have tried to make disciples through programs: The Scriptural context for growing disciples is through relationships ... Unless disciples receive personal attention so that their particular growth needs are addressed in a way that calls them to die to self and live fully to Christ, a disciple will not be made ... Since individual, personal investment is costly and time-intensive, we have put programs in place' (pp. 42-43)

3. 'we have reduced the Christian life to the eternal benefits we get from Jesus, rather than living as students of Jesus' (pp. 46-47)

4. 'we have made discipleship for super-Christians, not for ordinary believers' (pp. 48-49; cf. also Nel 2004:97-102);

5. 'leaders have been unwilling to call people to discipleship' (pp. 49-51)

6. 'we have an inadequate view of the church as a discipleship community. Biblical discipleship is never seen as a me-and-Jesus solo relationship, for the church is a discipleship community' (p. 51). He refers to Robert Putman's Bowling Alone (2000) making 'the convincing case that the social capital of religious life is being undermined by privatized faith' (p. 51)

7. 'most churches have no clear, public pathway to maturity' (pp. 52-54)

8. 'most Christians have never been personally discipled' (pp. 54-56).

Ogden (2003:54), who is not formally part of the so-called missional conversation, then states what he calls the heart of his book (and for those who know his work it may be fair to say of his research and publications as such). He (Ogden 2003) calls it:

[O]ur paradigm shift question: How can we grow Christians into self-initiating, reproducing, fully devoted followers of Jesus Christ? My conviction is that the primary way people grow into self-initiating, reproducing, fully devoted followers of Jesus Christ is by being involved in highly accountable, relational, multiplying discipleship units of three or four ... By discipling I mean 'a process that takes place within accountable relationships over a period of time for the purpose of bringing believers to spiritual maturity in Christ.' (His quote is from The Eastbourne Consultation, Joint Statement on Discipleship, September 24, 1999). (p. 54)

There is indeed a sometimes obvious negativity towards the concept and metaphor, even more so in the so-called mainline and 'more liberal circles' (Stoppels 2013:15). Stoppels (2013:67) gives as a fourth reason for his choice of the concept and his desire to restore the concept in its honour in his mainline denomination. My purpose is not to apportion blame in any way. I rather want to acknowledge with Stoppels (2013:13-17) that there is indeed what he calls an 'ecclesial turn' in our discussion. In many circles, whether mainline or among the so-called evangelicals, there is a new discovery of this neglected jewel in the crown of faithful missional churches. Stoppels (2013:13) chooses to go for discipleship and discipling in his book and does so under the motto: 'Jesus called learners, not church people'. ${ }^{1}$ Stoppels (2013:13) acknowledges that such an 'oneliner' is indeed not nuanced enough, but it does carry the dialectic tension which should exist in churches.

It is however not only Ogden and Stoppels who realise this missing link in our missional thinking. Many others

1.'Jezus roept leerlingen, geen kerkmensen. 
are concerned. And even though, it is as if I am missing an open willingness to discuss and 'promote' the concept and metaphor. It may very well be that the missional discussion had to get our thinking out of the paradigm of 'saving souls for heaven'. It has to help us discover what Guder (2000:97-143) calls and describes as the 'reductionisms' of the Christendom era. Together with Bosch (1991) we had and still have to rediscover that mission is God's 'yes' and God's 'no' to and in this broken world:

In our time, God's yes to the world reveals itself, to a large extend, in the church's missionary engagement in respect of the realities of injustice, oppression, poverty, discrimination, and violence. (p. 10)

Bosch (1991:73-83) in his book, has a section on discipleship and refers to Matthew's Gospel with the words: 'Matthew's paradigm: missionary discipleship' (p. 79). I purposefully refer to Bosch in this regard. His works (together with work done by Leslie Newbigin) influenced the missional conversation (and initially the Gospel and 'Our Culture' discussion and series) deeply. I do not know of any specific and in-depth references and further in-depth research on 'missionary discipleship' - admitting what I have stated above. This conversation is covered in such a variety of books, that I may just have missed some references. It may also be true that authors just accept that what they cover in their books is indeed related to 'missionary discipleship' even though it is not specifically stated as such.

One of the reasons may be a misunderstanding or lack of emphasis on evangelism within our new and challenging missional discussion and understanding. Understandably we are sensitive to perceptions of evangelism within the multi-faith discussion and dialogue. We need to be. Being missional is to understand a little of Jesus' inclusive thinking. Missional literature often refers to this inclusive nature of a missional church (cf. Gittins 2008:198; Clark 2005:72 to name but two). This may sometimes or often does lead to a lack of passion for sharing the good news. At the same time there is such a worldwide reaction against a sometimes very un-Christlike confrontational approach to evangelism that many theologians rather shy away even from the concept (cf. Nel 1997-1998, 2002, 2007; Stoppels 2013:67). Bosch (1991) refers to evangelism (his italics) as one of the 'essential dimensions' of mission.

Evangelism is the proclamation of salvation in Christ to those who do not believe in him, calling them to repentance and conversion, announcing forgiveness of sin, and inviting them to become living members of Christ's earthly community and to begin a life of service to others in the power of the Holy Spirit. (pp. 10-11)

When further on in his book (Bosch 1991:73-83) he discusses discipleship he makes no direct link to evangelism. Malphurs (2007:80-83) also does not connect, at least not in a direct way, evangelism with discipling. He (2007:79) names five functions that according to him are: 'timeless, unchanging, non-negotiable, based on the Bible.' The five are teaching, fellowship, worship, evangelism and service. Malphurs (2007:84) refers (without naming the source) to Rick Warren who has five purposes for the church, one of them being discipleship. The five are: evangelism, worship, fellowship, discipleship, and ministry.

To my mind this missing link may be one of the reasons for the often underdevelopment of discipleship ministries in congregations. Even when churches do evangelise, they do not see it as deeply related to the principle and the way in which we 'make disciples'. To my mind disciple-making is evangelising in its very core. Ott (Ott \& Wilson 2011) does connect the two:

Church planting is that ministry which through evangelism and discipleship establishes reproducing kingdom communities of believers in Jesus Christ who are committed to fulfilling biblical purposes under local spiritual leaders. (p. 8)

Armstrong (1979) did connect service evangelism and discipleship in a direct way:

[W]e show with integrity our belief in Jesus Christ as the Son of God if we ask ourselves what it means to be Christ's man or Christ's woman in the world today. The answer to that question defines the quality of our discipleship; and when church members take it seriously, the church will truly become a servant church. (p. 38)

(See also cf. Sjogren 1993:20ff. and what he calls 'servant evangelism=deeds of love+words of love+adequate time.')

We must understand the subtle distinction between evangelism and disciple-making. There is a difference. But: when disciple-making does not include evangelism and vice versa we get the situation we are in at present. Like congregations include youth so does disciple-making include the sharing of the good news of Jesus the Christ. The decisions we are looking for in evangelism should be for a commitment to a life of discipleship - and not to book a place in the waiting room of heaven. Stoppels (cf. 2013:87) refers to the seriousness of this choice to follow the Christ. It involves the totality of life, lifelong learning. In his own words (Stoppels 2013):

A learner of Jesus Christ is someone who, in the power of the Holy Spirit and in communion with (the) other learners, desires to learn with his or her total life to live life in following Him. A learner (disciple) is someone who sincerely directs/focuses his or her life on the Kingdom of God as Jesus Christ has embodied and proclaimed it. (p. 73) ${ }^{2}$

A further missing link in missional literature is the inclusive nature of the faith community itself. I cannot recall any reference to youth in the books on missional churches and the development of such communities. I just may have missed it or the authors may assume that youth is an integral part

2My free translation of: 'Een leerling van Jezus Christus is een mens die in de kracht van de heilige Geest en in verbondenheid met (de) kring(en) van andere leerlingen van de heilige Geest en in verbondenheid met (de) kninglen) van andere leerlingen over de volle breedte van zijn of haar leven het verlangen heeft te leren leven in zijn spoor en zijn leven daadwerkelijk en duurzaam richt op het Rijk Gods zoals Jezus Christus dat belichaamde en verkondigde.' 
of the body - which should be the case. My suspicion (and I may be totally wrong and I would be glad in case I am) is however that there is almost a subconscious 'adult' mindset when we write about the missional church.

What should be said in all honesty is that even when the concept and metaphor of discipleship is not specifically used there is a strong emphasis on teaching and learning. Most scholars know that 'learning' lies at the heart of discipleship. Even though it is not the focus of this article to explore this in depth, I do need to refer to the very good contribution by Osmer (2012:29-55) in a book published within the 'missional conversation'. To my mind 'formation' is not only necessary in developing missional thinking and practices, it is in itself discipling and should be disciplemaking as such. Osmer (2012) connects formation with discipling:

In contrast, the missional church leaders viewed the purpose of formation as cultivating a life of active discipleship in ways that represent both a break with the immediate past of the congregation and was more open to cultures of people not currently in the church. (p. 34)

\section{What kind of 'people' are best suited to make disciples in youth ministry - being before doing}

When evangelism is a power game churches loose their Godgiven Christlike identity and integrity. I will try to explore the kind of people who are best fitted to make disciples and help us get back what we have 'lost', even in youth ministry. To start with, I will use a rather lengthy part of the work of Gittins (2008). At one point (2008:185-189) he asks: 'Would Jesus recognize the Church? What Church would Jesus recognize?' In his discussion (pp. 161-198) he focuses a lot on the being (my italics) of the faith community. In quoting him (Gittins 2008) I hope that I am doing justice to a good piece of incarnational theology:

Unless there is some person of faith, then there is no faith; if hope is not carried by real people, then hope does not exist or has already died; if love is only found in the dictionary, the love itself has become extinct in the world. The Christian community lives 'in memory of (Jesus)' and is required to 'do this in memory of (Jesus)'. As the religion of incarnation and the faith of those who claim to know God, Christianity loses all credibility unless it is alive, not in cathedrals, creeds, or catechisms, but in people. It can only live in people if it is not just what they say they believe, but what they can be seen to do and how they actually live. (p. 161)

\section{And further (Gittins 2008):}

[A] Church relying on imperial, hierarchical, patriarchal, sexist model that is unquestionably broken ... surely cannot be fixed, whether by fiat or fad, and certainly not by fission. Some things are beyond simple fixing; they must be radically restructured 'restored' in the truest sense of 'brought back into existence; brought back to health'. (pp. 187-188)
But this is precisely why Jesus came (Lk 4:18-19).

Uninspired and timid solutions are not appropriate to those people inspired by the Jesus image of the realm of God; and cosmetic modifications cannot mask decay and necrosis indefinitely. In a world at once polarized by fundamentalist religions, secularized by the worship of mammon, and poisoned by the toxic fumes of postmodern nihilism, what is urgently needed is a new awakening and a concerted effort on the part of the few, to be conformed to Jesus. It is highly unlikely that this will be a widespread or popular movement ... If true restoration is to happen (which is far from nostalgia-driven 'restorationism'), it is certainly necessary to activate the virtue of hope that characterizes true Christians (1 Peter 3:15).... Does the Church - as institution, as hierarchy, as patriarchal hegemony - have the will and the capacity to turn and be converted? (Gittins 2008:188-189)

With reference to the purpose of the church according to scripture he (Gittins 2008) writes:

The church was not intended to take over or become the plenipotentiary in charge of God's mission; the Church was called to be a servant, committed to the service of the realm of God. As sacrament or sign of God's reign therefor, the Church should always point beyond itself, to the one who is the Way, Truth, and the Life, redirecting seekers and searchers in Jesus' name, so that they do not become hopelessly lost. (p. 190)

We are called to be a 'Church for sinners and Community of Saints' (Gittins 2008:192).

And then a paragraph (Gittins 2008) that is of vital importance to our research theme:

There will always be need for the Church as community called and sent by Jesus. But it will always be called to be a community of inclusive table fellowship and gracious foot washing, a boundary-breaking rather than a boundary-maintaining community, and a community of mission more than a corporation of maintenance. But in order to do this faithfully and well, it will always be in need of repentance and always called to inspire and cultivate a discipleship of equals, because it will always need to remember that Jesus said 'you also should do as I have done to you' (John 13:13-15). This I submit is the only authentic way we can be disciples, the only honest way to be missional, and the only appropriate way to be Church. (p. 198)

One may say that 'learning' and coming to terms with 'our' own brokenness is almost a prerequisite for disciple-making churches. The New Testament scholar Van Aarde (2006: 103-122) wrote his article on how to 'come in' and 'stay in'. He explores the understanding of the Gospel of Matthew with regard to discipleship and disciple-making (as does Bosch 1991:73-83). This because:

$[T]$ he theme of discipleship is central to Matthew's Gospel and Matthew's understanding of the church and mission... 'The verb occurs only four times in the New Testament, three of these in Matthew (13:52; 27:57; 28:19) and one in Acts (14:21).' (p. 73)

Willard (1998:3) wrote: 'the New Testament is a book about disciples, by disciples, and for disciples of Jesus Christ' (also cf. Willard 2006; Stoppels [2013:66] for similar arguments). 
Van Aarde (2006:107) openly declares that the conversion of the church is a prerequisite for our legitimate missional involvement in this world (cf. Guder 2000). He builds on the exegetical background of Matthew 28:18-20. According to him (2006:103) Matthew 28:16-20 is an almost direct account of the Greek translation of the Aramaic text of Daniel 7:14. With reference to Schlatter ([1933] 1963:797) this promise of God's presence relates to Paul's use of being 'in Christ'.

My purpose is not an exegetical exploration. My purpose is to employ the research by a world-renowned New Testament scholar and hopefully contribute to a discussion on what kind of faith community (church) will get back to a normal practice of a disciple-making ministry. According to Van Aarde (2006:112-113 my free translation of the Afrikaans):

Matthew 28:16-20 has been described as the manifesto (Von Harnack in Frederick D. Bruner 1990:1094) of the church - a manifesto that is on the same level of value as the Shema of Israel (Ernst Lohmeyer 1967:416): 'Hear, O Israel: the Lord our God, the Lord is one' (the Afrikaans translation used by Van Aarde is: 'the only Lord'). This manifesto wants to say to us how radically new we have to think about how people come in and stay in. This 'coming in' and 'staying in' is not without tension. This manifesto must be seen in the light of the cross and the resurrection account in Matthew: The dying of an old dispensation and the dawn of a radically new dispensation (see Van Aarde 1998a; cf. Trilling 1969). In this radically new dispensation one finds in Matthew an imperfect ('onvolledig') church that cannot, like the 12 of old, claim a certain humanly roundedness - even the twelve has change to the eleven after Jude, Iscariot left - the broken group (church), the 'sinners church'. It is this broken church that receives the great commission - not a perfect church, but an imperfect one, the elevenish (Bruner 1990:1090) church. (pp. 112-113)

In this regard it is important to consider the important role that Matthew 5:3 plays in the understanding of this Gospel: 'Blessed are those who know how dependent they are upon God' - the so-called 'poor in spirit' (NIV) - 'Theirs is the kingdom of heaven' (also cf. the title of Sjogren 2002).

To look at it one more time from another angle: Van Aarde (2006:106-107) refers to a monograph by Barth (1932:189-215) on the humanness of God. Barth reflects in the monograph on the acquisition that dialectic theology is apathetic towards mission. He points out that we should not too easily speak of and make a distinction between 'insiders' and 'outsiders': "Even the most convinced Christians should recognise themselves as 'outsiders'. We who are in the church should remember that the church is indeed a 'heathen church', a 'tax collector church' - meaning that we as people in the church plead with God to have mercy on us 'pitiful sinners'. To be faithful in mission we are asked to 'turn around' (convert). As far as those outside of the church are concerned we should think of the 'outsiders' as implicit 'insiders'. You ought to think of the 'outsiders' as people you want to see as being 'inside'. The outsiders are 'the church on the other side' (cf. Mclaren [1998] 2000:121-143). Blauw (1962) has noticed this already in his reflection on the Old Testament:
All the emphasis falls on the fact that the world of nations is a gift to the Messianic Servant; there is no reference here to the world as a 'mission territory' of the Servant. (p. 43ff., [italics original])

According to the Gospel of Matthew we should realise that disciples are not 'in' because we have managed to get in on our own and by our own doing. The relational character of the covenant is important in understanding this attitude of the church that is in the discipling ministry. God brought us in and on the 'inside' we should never lose sight of this: we should remember where we come from and who we are (Van Aarde 2006:110). The message of Matthew is that those outsiders (people of whom no one takes notice [Mt 5:3]), truly outsiders, will inherit the Kingdom. Van Aarde (2006:111) relates this understanding directly to the Pauline understanding of being at the same time 'old' and 'new' and as Paul asks of Israel never to call self-righteousness, God's righteousness (cf. Rm 10:3). According to Van Aarde (2006:114-117) Matthew helps us to understand this 'incongruity'. The great commission is built upon two pillars:

One is to see and acknowledge your own ambivalence: you believe but you also struggle to believe. You acknowledge your own inability - you only build on and live by grace alone. When we internalise this attitude we will no longer handle or view or approach those who are still outside with prejudice. The second pillar is taking, what Paul Tillich (1948:118) called the 'protestant principle', serious: The protestant principle is to scrutinise all traditions, cultural and denominational, in light of the gospel. It means to see ourselves as in this world, but not part of it in the sense that the ethos of the world becomes our 'gospel'. This can only happen when the manifesto of Jesus - (what Paul calls the 'law of Christ') - is in the centre of our lives. Jesus summarised it as loving God and loving the other as we love ourselves. (cf. Van Aarde 2006:117-118)

How would this broken and vulnerable group have heard the words of Jesus in Matthew 28:18-20? It is the last time we hear of the disciples in this Gospel. It is the end of the Gospel.

Exegesis asks: What happened to them before this grand finale? They ran away from the cross while a few courageous women brought them the news of the final victory of the resurrection ... We would have expected a change. But Matthew's account is the same old story: some of the disciples who wanted to walk on the water with him, but could not; who wanted to be in Gethsemane with him but could not stay awake; who wanted to go to Golgotha with him but could not, are now, even though they worship him, still in doubt! It is [sic] such stumbling followers (disciples) that listen to the manifesto. And what echo's in our ears is the ambivalence of believing and 'doubting at the same time (Matt 14:31; 28:17).' (Van Aarde 2006:113)

This imperfect 'church' hears the commission. The verb 'to go' (poreuthentes - Mt 28:19) they heard is not a strong verb - not in the grammatical form of a command, but an infinitive. It is like 'I am going to eat'. Not to be understood as command: GO and eat! What is imperative in what they hear is 'make disciples (matheteusate), make the church one large school of Jesus followers' (Van Aarde 2006:114; also cf. Wilson 1979). 
How should we then hear it? In the words of Van Aarde (2006) we should:

$[I]$ nternalise in a confessional way the message of Matthew. We should invite anyone (all) in an unconditional way to come and share this confession with us: the confession that God, in and through Jesus of Nazareth - Christ the Lord, the victorious Son of Man - is God-with-us. He is with us as long as there will be days, and as long as we do what Jesus, in love, did and taught. (p. 117)

\section{Reforming and transforming local faith communities into disciple- making movements}

What will we have to change in our Christian education (teaching and learning) for youth ministry to reform and transform local faith communities into disciple-making movements? It is this question that to my mind takes my previous (Nel 2009) article further. I have argued the case that the making of disciples at least covers the following:

\section{We need to recover (and stop devaluating) the concept of discipleship}

Therefore, New Testament discipleship reminds us of the Old Testament bond between God and his people. What distinguishes New Testament discipleship is the Person and Work of Jesus, who calls people to become his disciples. While the initiative in Rabbinic Judaism lay with the individual to join the righteous (with the pupil choosing the rabbi), it is Jesus himself who saw, chose, and called his pupils. Although there are examples of such occurrences in Greek literature, it remains a dimension unique to the Gospels. The accent is exclusively on the person of Jesus, with the truth explaining the strong emphasis on his words in the context of discipleship (cf. Jn 8:31, 15). After the Resurrection, too, the disciples rallied round the risen Person of the Christ (and his words). While rabbis and Greek philosophers all presented a specific subject to their pupils, Jesus Christ presents (sacrifices) himself. Two things constitute biblical discipleship:

- acceptance into a personal relationship with Him who calls you to belong to Him; and

- a vocation, which means that you have to be a follower and pupil of the Christ who has called you. (Nel 2009: 2 of 11; also cf. Rengstorf 1967:446).

In my article (2009) I summarised it as follows:

In other words, according to Rengstorf (1967:406), Jesus's concern is not to impart information, nor to deepen an existing attitude, but to awaken unconditional commitment to Himself. That mathytys, as akolouthein, is also manthanein, is self-evident (Mt 11:29). In contrast to both Rabbi Akiba and the philosopher Socrates 'Jesus binds exclusively to Himself' (Rengstorf 1967:447). In addition, according to Louw and Nida (1988: 470-471), the verb 'to make disciples' (mathyteusate) refers to disciple in the sense of adhering to the teachings or instructions of a leader and promoting the cause of such a leader ... In many languages the equivalent of 'to follow' (in the sense of 'to be a disciple' is literally 'to accompany' or 'to go along with' or 'to be in the group of'. Louw and Nida (1988:471) also state that the verb means to 'cause people to become followers ... In order to avoid a wrong implication of a causative it may be important to use such expression to 'convince them to become disciples' or 'urge them to be my disciples'. (Nel 2009:2 of 11, [italics mine])

I still believe that this is a critical issue. Faith communities need to continuously rediscover the meaning of being disciples of Christ, the Lord. In a recent publication Smit, (2014: position 203 of 1327) on the letter of James, wrote:

In the tradition of Bonnhoefer and Kierkegaard we often distinguish between admirers, learners (pupils) and disciples of Jesus. Admirers are those who respect the life and teachings of Jesus and may even often quote these. They admire him as the best among men and like to listen to his words. Pupils are people who study his teachings, they know these teachings inside out, can talk about them and even teach them. Disciples are those whose life is destiny bound with Christ, whose life has been touched and changed by him and his Spirit, people who no longer live for themselves but for him and for others. (Freely translated from the original Afrikaans by author)

Stoppels (2013:78ff.) states that he is convinced that there are good grounds to think about building up local churches from the viewpoint of discipleship. I did so myself in 1994 already (Nel 1994:83-96, 2004:97-111). Stoppels (2013:78ff.) describes discipleship from 10 perspectives. It seems necessary to me to help local faith communities to get a good understanding of these multiple perspectives:

\section{Discipleship:}

- presupposes community

- puts us on a road of being a counter voice

- takes us out of serving the church

- makes one what is divided

- puts us on a journey of growth

- asks for discipline

- unifies humble leaders and humble (modest) ordinary members $^{3}$

- is not for consumers

- should not be confused with religious virtuosity

- is like a boomerang for the church's offer (p. 78ff.).

\section{'We' have to change: only disciples can make disciples ...}

In light of my description of the church in the previous point it can be expected that I will argue that the first that will have to change is 'us'. Only disciples can make disciples, who will also make disciples, who will make disciples ... until

3.In the conversation with Darrell Guder (2014) referred to below he answered a question concerning leadership in the missional challenge as follows: 'I think the first thing is that we must become trusted conversation partners of our the first thing is that we must become trusted conversation partners of our congregations. To use Presbyterian lingo here, the teaching elder, the theological servant of the church, has got to liberate herself or himself from any suggestion of spiritual superiority, of any kind of priestly specialness that makes us into a special caste of Christians. We need to be brothers and sisters of our congregation, friends, empathetic learners with them, of the reality of the world in which God has sen us. We have to earn the right to be heard as a biblical and theologically informed friend and conversation partner. That trust has to develop so that together we can understand the challenges that society presents to us.' 
Jesus comes again. The rhythm can only be restored when faith communities are being reformed and transformed, rediscovering their own disciple identity (cf. Nel 2015). Previously I (Nel 2009) have phrased this as follows:

Only if we are the invitation, dare we extend the invitation ... Inevitably, some are closer to the young than others: Parents, whether separated or together, divorced or widowed, broken or in the healing process, are ideally situated to be the invitation. Whoever is related to a child has a God-given relational (covenantal) opportunity to be the invitation. (p. 7 of 11)

Making disciples in youth ministry is far more than just another program or a few adaptations to what and how we teach. Dean (1998:25-39) calls it a movement from 'programs to people'. I am convinced that when we rediscover and recover our identity as disciples we reform and transform our faith communities. We do so in a faithful and in a somewhat natural way because we grow in understanding (hermeneutical work of the Spirit through Word, Sacrament and community) of who God is and who we are. We also transform and reform by way of a more intentional systemic process. In this process of rediscovering we will have to start small by preaching and teaching about our identity, trusting God that he will call people anew to an understanding of being called in. Being called to identifying with him, allowing him to continually change 'us' into the likeness of the Son (cf. 2 Cor 3:18-20). In missional literature there are so many important pointers on how to develop such a church. What I add is in a sense a dimension that to my mind is not covered sufficiently in the current discussion. We purposefully have to focus on the recovery of our very being, being learners. 'The missional church is a community where all members are involved in learning to become disciples of Jesus' (Barrett 2004:160). In rediscovering missional identity we need to rediscover and recover that we learn how to live life faithfully - the Christ way. Osmer (1990) once said that often when we want to recover something we first have to rediscover what we have lost:

Rediscovery is the activity of discerning once again the meaning and power of tradition that has been repressed or forgotten. Recovery goes further. It involves the positive evaluation and appropriation of that tradition, using what has been rediscovered to structure present patterns of thought and action. (p. 141)

This is indeed my understanding of reformation and transformation. This takes time and lots of ministerial energy (cf. also Dean 1998:35 for her 'continuum for youth ministry').

We can do this at a time that there is new energy to be sincere about who we are. Brueggemann (2006) already wrote:

Does it strike you that congregational life for the most part is remote from such deeply rooted, biblical understandings of discipleship and evangelism? Well, yes. Much congregational life has so fuzzied the claims of the Gospel in order to accommodate to culture that the church, only with difficulty, can be a truthteller in the face of denial and a hope-teller in the face of despair. It is clear now, is it not, that this is a new time in the church. It is a time when many people, with deep ambiguity, want an alternative with a deep sense that dominant patterns of life in our society simply are not working. There is a hunch and a wish, guarded to be sure, that the church should let the news, with all its implications, has [sic] its say. Such a say depends upon preachers who risk, supported by congregations who will stand by in solidarity. (p. 112)

\section{And earlier Brueggemann (2006)) stated:}

The disciplines function to inconvenience us enough that we become conscious, self-conscious, and intentionally aware of who we are and what we are doing with our lives ... I submit that only those who are inconvenienced enough to be intentional will have the energy for mission. (p. 109)

Stoppels (2013) right through his book is arguing a case for rediscovery and recovery of this biblical truth. He (2013: 64-67) motivates his choice for discipleship in four ways. The first being the central place of the concept and metaphor in the New Testament. He (p. 63) links up with a quote from Bonhoeffer (2001:59): 'Christianity without the living Christ is inevitably Christianity without discipleship and Christianity without discipleship is always Christianity without Christ. It remains an abstract idea, a myth.' As already noted Stoppels (2013:16-17) calls it 'the ecclesial turn'. In his reflection (2013:42-45) on what he calls a sociological perspective, he mentions the importance of the community of disciples - because 'people need other people to stay actively faithful to life-convictions, even when this is not in line with common sense (his italics) in the present society.' In more than one way he argues for the church to be such a community where we are disciples and are involved in the making of disciples - however, this may not be the 'in' thing in an individualistic society. In describing his ecclesiological viewpoints he reflects on the relationship between individual and community (Stoppels 2013:50-52). His conviction is that we may miss something in the 'shop behavior' and consumer mentality of individuals. What they do 'desire' ('verlangens') is 'sincere forms of a faith community, a space where they experience God and real mutual relationship with one another. ${ }^{4}$ Stoppels (2013:99ff.) is convinced that two important issues that go together are: 'community formation and discipleship'. He (2013:24-38) enters into a discussion with well-known scholars like Heitink (2007) and Hendriks (2008) and a number of others. After a paragraph on 'Arguments for a Counter Culture' he (2013) wrote, with reference to Henk de Roest (2010:77), that:

[The] church always and in principle has her center, her core, her 'middle point' outside of herself. Therefor when she is close to her center, she is evenly outside of herself. (p. 48)

He (p. 48) then continues to say: 'discipleship places the church in that sense outside of itself and in this sense the church can become more herself ${ }^{\prime}{ }^{5}$ In a very recent interview

4.My free translation of "waarachtige vormen van geloofsgemeenschap, naar een plek waar God ervaarbaar wordt en de onderlinge gemeenschap voelbaar.'

5.My free translation of 'zij heefte haar centrum, haar kern, haar midden, altijd en principieel buiten zichzelf. Derhalwe, wanneer zij dichtbij haar kern is, is zij even buiten zichzelf' and of 'Dsicipelschap plaats the kerk in zekere zin buiten zichzelf en juist zo kan de kerk meer en meer zichzelf worden. 
Guder (2014) responded to a question concerning challenges in the missional conversation:

I also have to say, when you begin digging more deeply into our missionary vocation, then the resistances begin to surface. We encounter in the Scriptures a difficult gospel, because it means that we must recognize our own captivities, we must recognize that there are many ways that North American culture opposes Christian living, and we must deal with that. We don't like that. We don't like to be on the margins, but we are a minority. So how do we get used to being a minority and then function with freedom and joy as Christian witnesses, knowing that there are many things that we are doing and concerned with that our society does not particularly welcome? (n.p.)

The conversion of the 'we' has never been easy.

\section{Disciple everyone involved in youth ministry}

While continuing this process of developing 'missionary discipleship' (Bosch 1991:79) youth ministry can be transformed by intentionally discipling all the members involved in youth ministry. I think especially of the parents and 'volunteers' (both younger and older) involved in Christian education. Missional churches must rethink what they do in faith development. Dick (2007) describes the situation as follows:

Promoting a love of learning and developmental plans are high priorities in vital congregations. Vital churches have a clear picture of what it means to be a Christian believer, a Christian disciple, a Christian leader, and the body of Christ. (p. 118)

Youth ministry often did not take this seriously enough. We have allowed people to be involved who were not serious (at least not enough) about their own 'being in Christ' and with discipling children and adolescents. Campolo wrote in 1995 (p. 133) already: 'Of all the failures of mainline churches over the last three decades, none has been more pronounced than their failure in Youth ministry.' Being a faithful learner, follower, and disciple of Christ is a prerequisite for being involved in any form of youth ministry.

This may even be more specifically true for teaching in youth ministry. No one doubts that youth ministry has always been, still is and should be educational in tone. What went wrong is that this basic notion has often taken a 'scholastics' turn. And as such it is no longer in ministry terms educational. When teaching is not relational, it has almost no place in youth ministry. It certainly will not be 'cultivating a life of active discipleship' (Osmer 2012:34). My conviction is that many books that are indeed helping us with teaching (cf. for example two such good books Lambert 2004; Rothnagel, Schlag \& Schweitzer 2014) are very pedagogical in approach. Teaching should be pedagogically grounded and in a scientific way be educationally sound, but how will it differ if we do not just 'teach' pedagogically correct but, within a relationship of love and acceptance, make disciples through our teaching? I believe this lies more on an attitudinal and cultural level than on a pedagogical level. Osmer (2008:178), with reference to Quinn (1996:201), thinks that 'deep change' lies in a change in 'identity, mission, culture, and operational procedures.' It is my conviction that what we need in the case under discussion is a change in culture within missional and disciple-making churches. One example: It may be wise and show forth our change in culture when we do not refer to 'classes' anymore but to youth groups - where inclusive relationships of love and acceptance are as important (if not more) than the content we need to teach correctly -or as Lambert (2004:11-36) calls it 'holistic teaching' (cf. also Borgman 2013:269-287).

What will be characteristic of congregations where the understanding is growing that they are learning communities? This may help us to understand how we intentionally can change the culture that will benefit disciple-making in youth ministry. I want to stay true to my intention to draw Stoppels (2013: 136-140) into this discussion again. He refers to research by the Indianapolis Center for Congregations (2012) (see for the website in the bibliography) where seven elements are named that will 'enhance the learning potential of faith communities' (p. 136):

- congregations that learn well find and use outside resources

- congregations that learn well live within a worldview of theological coherence

- congregations that learn well ask open-ended questions and practice active listening

- congregations learn well when clergy and laity learn together

- congregations learn well by attending to rites of passage

- congregations learn well when they slow things down

- congregations learn well when they say 'no' and when they say 'yes'. ('without sincere priorities and clear choices [even when sometimes painful] no church sails well') (Stoppels 2013:140). ${ }^{6}$

The issue at stake in this paragraph is: Only involve and employ 'volunteers' in youth ministry who are serious about their discipleship. I have tried above to 'outline' what kind of faith community or congregation will be such a fertile ground to supply this quality of volunteers. Congregations who are serious about the gospel of the Kingdom as they live by the ethos of the King will do so. Stoppels (2013:117-118) points out that this is more than looking for people who are actively involved, especially in the worship services the typical evaluation of membership. We should look for a different expectation: An expectation that has to do with 'the teachability of people and their openness for a specific lifestyle based on and seeking for the Kingdom of God"7 (cf. also Osmer 1990:52 and his reference to a prayer of John Calvin that God may bring his mind to a 'teachable frame'). With references to De Roest (2010:167) and to Wolsheimer (2012) Stoppels (2013:117-118) discusses this 'seriousness' about

6.My free translation of 'Zonder echte prioriteiten en heldere keuzes (ook al zijn ze soms pijnlijk) vaart geen kerk wel.'

7.My free translation of 'verwachtingen die te maken hebben met de leerbereidheid van mensen en hun openheid voor een bepaalde levenstijl die gefundeerd is op en leidt naar het Rijk Gods.' 
who we are in Christ. We live by a discipline that flows from our discipleship. De Roest translated the disciplina arcani as the 'secret rule of life' ${ }^{8}$ And while Wolheimer acknowledges the importance of a confession of faith, he thinks that the church has a higher level of need for a confession of life. Wolheimer (2012:103) discerns eight 'fields of attention' ('aandachtsvelden'): 'seeking God (will), prayer, work, study, spiritual community, caring for your body, caring for other, and hospitality' (cf. Stoppels 2013:118).

This is the Rule we embrace. This is the Rule we will keep: we say yes to availability; we say yes to vulnerability... A rule is basically a way of life, not a book. (Wolsheimer 2012:110; cf. 'What kind of 'people' are best suited to make disciples in youth ministry - being before doing' above)

My conviction is that there is no way to reform and transform local churches or reform and transform youth ministry other than by taking our God-given identity as vulnerable people saved by grace serious, very serious. Even our leaders in local churches, especially the trained theologians, should make a clear choice about their core contribution: Are they fulfilling often odd jobs or are they equipping (as they grow themselves) the core membership to 'as they go, make disciples ...'? (cf. Stoppels 2013:60ff. for his discussion on where leaders should focus: the margins or on 'the core' ['de kern']?)

\section{A re-evaluation of individuation}

Lastly I would like to focus on one more dimension of ministry that might help us transform youth ministry and thereby faith communities into disciple-making movements. Clark (2001:47-51) describes 'individuation (as) a key to understanding adolescent development.' However true that might be, and it is, we will have to, more intentionally, help everyone involved in human development (the parent(s) who 'carried' them, brought them into the life given by God and everyone else along the line) to realise that we never meant by 'individuation', individualisation. Within a culture where individuality and individualism have become the new gods we need to make a special effort to counter this dehumanising tendency in culture and, almost subconsciously, in youth ministry. Jung (1971:448) who worked with this concept refers to individuation as 'a process of differentiation, having for its goal the development of the individual personality.' In my article on 'Youth ministry: a challenge of individuation' (Nel 2003:151-196) I have tried to point out (in close relationship with the work of Osmer (1996:9-26) that a theological perspective on 'individuality', individualisation and individuation are necessary in youth ministry. We certainly do not want to support the very nature of our sinful nature 'doing and having it my way'. Our very creation challenges this way of being human: We were born from 'two people knowing' one another; we were born (or were supposed to be born) into a small community of love and caring; within a cultural unit; a national community; and in our case, a faith

8.My free translation of "leefregel voor het geheim.'

9.My free translation of 'Geloofbelijdeni' en 'levensbelijdenis'. community. In South African culture the following saying is well known: 'umuntu ngumuntu ngabanye'! (isiZulu for 'humans are humans through other humans' - with reference to 'interdependency'). Two older scholars have said it so well. Firet (1986:145ff.) and Allport (1961:33) point to our becoming and what role our original system (DNA) and the society play. Allport said: 'personality $=\mathrm{f}$ (inheritance) $\mathrm{x}$ society' (1961:33). We were born for community, and in communion with others we flourish and become our true self. Böggeman (1985:108) describes a 'selbständige Persönlichkeit' as having autonomy, sociability, productivity, sexuality, and creativity in balance (also cf. Borgman 2013:102-113).

This process of becoming the self, in a theological sense, will be enhanced by a serious effort to involve people who have been on the journey longer with each child and adolescent. Dean (1998:41-54) calls this person a 'Godbearer'. She rightfully refers to what I argued above namely that such a 'Godbearing Life' has certain 'ingredients' (Dean 1998: 105-138). Part of it is a 'circle of friends: inviting spiritual friendships' (p. 123). Osmer (1996:202-210) pleaded for a mentor in the life of adolescents in the confirmation group. Even where fathers and/or mothers cannot be the early church 'sponsors' or 'godparents', disciplemaking churches should find other mentors to fulfil the role of spiritual mentoring in confirmation. In literature more specific focused on discipling, mentoring is also an important concept. Gibbs (2012) refers to it in the following way:

Christian character needs time to develop and mature for the gifts to be expressed appropriately. There will be missteps along the way, and early attempts may not be that impressive. Each person requires training, mentoring and honest evaluation. (p. 153)

Ogden (2003:123-129) describes this notion as part of what he calls a discipling relationship: 'Missing from this approach is the priority of relationships' (p. 123). Discipling relationships:

- 'are marked by intimacy, whereas programs tend to be focuses on information' (p. 124)

- 'involve full, mutual responsibility of the participants, whereas programs have one or a few who do on behalf of the many' (p. 125)

- 'are customized to the unique growth process of the individuals, whereas programs emphasize synchronization and regimentation' (p. 125) (also cf. Borgman 2013:83-101)

- 'focus accountability around life change, whereas programs focus accountability around content. Growth into Christlikeness is the ultimate goal' (p. 126)

- 'are centered on incorporating the life of Jesus in all we are in the context of all that we do'(p. 126).

Ogden (2003:127-129) continues by stating:

In an impersonal world, people hunger for intimacy, personal care, deep friendship and spiritual bonding. This is particularly true for men ... It takes time ... This means having enough vision to think small. (p. 127) 
In the model he (Ogden 2003) proposes:

[T]hree people journey together for a year to a year and a half while they grow toward maturity and being equipped to disciple others. As this relationship comes to a close, the challenge comes to each person to invite two others into the same walk of faith and then reproduce, and so on. Over the five- to seven-year period of multiplying discipleship triads, it is common to have eight to a hundred or more people who have been carefully groomed in the context of an intimate relationship. This number of self-initiating, reproducing disciples has a tremendous impact on the climate of ministry. It takes only 10 to 20 percent of a congregation to set the tone for the whole. Invest in those who will set the pace for the rest. At the same time one's leadership based is greatly expanded. (p. 128)

Youth ministry is an inclusive congregational ministry and every differentiated part of it should be saturated with this relational attitude: I am because and only when we are (cf. Nel 2000:77-97). We therefore need to intentionally build relational structures in youth ministry that will be discipling in a truly biblical way. Root (2007:205-207) wrote in a paragraph on spiritual growth, discipleship and vocation:

Therefore, relationships of place-sharing can provide the context for understanding and participating in discipleship in the faith community, for discipleship is born of uniting with one another as together we follow Christ. (p. 206, [italics original])

And again 'catechesis can be done within social relationships between adult and adolescent' (Root 2007:208). Ogden (1998, 2003) focuses on the relational and corporative essence of the church: 'The church of Jesus Christ is nothing less than his corporate replacement on earth. Jesus continues his incarnation by dwelling in his people' (Ogden 2003:31). The plural, the $u s$, has to be discovered. Dick (2007:92) reports on a study in 717 congregations: "“We" is the word spoken most frequently in vital congregations.' In disciple-making this we starts with the parent or parents. Nelson and Jones (2011) noted, to my mind correctly:

Family ministry is the process of intentionally and persistently coordinating a congregation's proclamation and practices so that parents are acknowledged, trained, and held accountable as primary disciple-makers in their children's lives. (p. 15) (also cf. Freudenburg \& Lawrence 1998)

\section{In conclusion}

Stoppels (2013:129) refers to Breen and Cockram (2009:23ff.), stating that in disciple-making communities the modes of ministry will be operational. Firstly will be classical training and educational opportunities and ministries. (I can almost hear the call from Ephesians 4:11-16: finally someone gets it. It is about training the faithful to be equipped for ministry, in this case the development of a missional). The second mode is the stage of 'apprenticeship' - the original meaning of the concept of mathytys. We learn by walking with the other and by 'on the job training'. The third mode is about being immersed in a new culture where you almost do not even know that you learn - like learning your home language. The three should function in combination, thus creating the most fertile learning processes. Thus the local faith community becomes a space to practice how to live life, learning from the Christ within a discipleship community. Here 'we' are serious about the Christ secret: being called and being challenged: 'If anyone would come after me, he must deny himself and take up his cross and follow me.' (Mt 16:24ff.). According to the Gospels this is the only way to have a life - a life so full that it is worth dying for. In a chapter on 'Something to die for' Dean (2004:29-53) describes in a profound way that adolescents may be 'dying for something worth dying for' (pp. 30-32). I would also relate her description of mimesis (p. 45ff.) to my understanding of a life of discipleship. We are after all, as Dean (2004:43) points out not challenged to suffer for Christ, but 'to love [her italics] in Christ's name.' We are teaching and learning in our space of practice ('oefenruimte' Stoppels 2103) so much so that 'his desires become our desires, and his story becomes our story' (Dean 2004:51). Folmsbee (2007:39) refers to re-culturing youth discipleship and remarks that 'discipleship is not solely about learning more about God. It is about learning how to live one's life to glorify God' (also quoted by Weber 2014:80):

Imagine we help youth to:

- celebrate inclusion,

- celebrate learning how to live life and

- celebrate developing (however challenging) a sensitivity to choose what matters most in life (cf. Phlp 1:9-11)!!!

\section{Acknowledgements Competing interests}

The author declares that he has no financial or personal relationships which may have inappropriately influenced him in writing this article.

\section{References}

Allport, G.W., 1961, Pattern and growth in personality, Holt, Rinehart \&Winston, New York, NY.

Armstrong, R.S., 1979, Service evangelism, Westminster, Philadelphia, PA.

Barth, K., 1932, 'Die Theologie und die Mission in der Gegenwart', Zwischen den Zeiten $10,189-215$.

Barth, K., [1956] 1960, The humanity of God, transl. J.N. Thomas from the original Die Menschlichkeit Gottes (Theologische Studien), Zollikon- Zürich: Evangelischer Verlag. John Knox, Richmond, VA.

Barrett, L., 2004, Treasure in clay jars: Patterns in missional faithfulness, Eerdmans, Grand Rapids, MI.

Barrett, L., 2006, 'Defining missional Church,' in J.R. Krabill, W. Sawatsky \& C.E. Van Engen (eds.), Evangelical, ecumenical, and Anabaptist missiologies in conversation: Essays in Honor of Wilbert R. Shenk, pp. 177-183, Orbis Books, Maryknoll, NY.

Blauw, J., 1962, The missionary nature of the Church, Eerdmans, Grand Rapids, MI.

Böggeman, W., 1985, Jugendfreizeit und Jugendarbeit in der Krise: Lebenswelt junger Menschen als Perspektive für eine offene Jugendarbeit, Ferdinand Schöningh, München.

Bonhoeffer, D., 2001, The cost of discipleship, SCM Press, London.

Borgman, D., 2013, Foundations for youth ministry: Theological engagement with teen life and culture, Baker, Grand Rapids, MI.

Bosch, D.J., 1991, Transforming mission: Paradigm shifts in theology of mission, Orbis, Mariknoll, NY.

Breen, M., \& Cockram, S., 2009, Building a discipling culture, Zondervan, Grand Rapids, MI.

Brueggemann, W., 2006, The Word that redescribes the world: The Bible and discipleship, Fortress Press, Minneapolis, MN.

Bruner, F.D., 1990, Matthew, vol. 2, the churchbook: Matthew 13-28, Word Publishing, Dallas, TX. 
Campolo, T., 1995, Can mainline denominations make a comeback?, Judson, Valley Forge, PA.

Center for Congregations (Indianapolis), 2012, How your congregation learns, viewed 19 November 2014, from http://centerforcongregations.org/resource/how-yourcongregation-learns

Clark, C., 2001, 'The changing face of adolescence: A theological view of human development', in K.C. Dean, C. Clark\& D. Rahn (eds.), Starting right: Thinking theologically about youth ministry, pp. 41-62, Zondervan, Grand Rapids, MI.

Clark, D., 2005, Breaking the mould of Christendom: Kingdom community, diaconal church and the liberation of the laity, Epworth, Werrington.

Dean, K.C., 1998, The Godbearing life: The art of soul tending for youth ministry, Upper Room, Nashville, TN.

Dean, K.C., Clark, C. \& Rahn, D., 2001, Starting right: Thinking theologically about youth ministry, Zondervan, Youth Specialties, Grand Rapids, MI.

Dean, K.C., 2004, Practicing passion: Youth and the quest for a passionate church, Eerdmans, Grand Rapids, MI.

De Roest, H., 2010, Een huis voor de ziel: Gedachten over de kerk voor binne en buiten, Meinema, Zoetermeer.

Dick, D.R., 2007, Vital signs: A pathway to congregational wholeness, Discipleship Resources, Nashville, T.N.

Easum, W.M., 2001, Unfreezing moves: Following Jesus into the mission field, Abingdon, Nashville, TN.

Firet, J., 1986, Dynamics in Pastoring, Eerdmans, Grand Rapids, MI.

Folmsbee, C., 2007, A new kind of youth ministry, Zondervan, Grand Rapids, MI.

Freudenburg, B. \& Lawrence, R., 1998, The family friendly Church, Group, Loveland, $\mathrm{CO}$.

Gibbs, E., 2012, The journey of Ministry: Insights from a life of practice, InterVarsity, Downers Grove, IL.

Gittins, A.J., 2008, Called to be sent: Co-missioned as disciples today, Liguori Publications, Liguori, MO.

Guder, D.L., 2000, The continuing conversion of the Church, Eerdmans, Grand Rapids, MI.

Guder, D.L., 2014, 'A missional conversation with Darrell Guder. A conversation on missional church between Guder and Forge Canada', viewed 10 March 2015, from http://www.forgecanada.ca/a-conversation-with-darrell-guder/

Heitink, G., 2007, Een kerk met karakter: Tijd voor heroriëntatie, Kok, Kampen.

Hendriks, J., 2008, Verlangen en vertrouwen: Het hart van gemeenteopbouw, Kok, Kampen.

Jung, C.G., 1971, Personality types, Princeton University Press, Princeton, NJ.

Lambert, D., 2004, Teaching that makes a difference: How to teach for holistic impact, Zondervan, Youth Specialties, Grand Rapids, MI.

Lohmeyer, E., 1967, Das Evangelium des Matthaüs, W. Smauch (Hrsg.), 4. Aufl., Vandenhoeck \& Ruprecht, Göttingen.

Louw, J.P. \& Nida, E.A. (eds.), 1988, Greek-English lexicon of the New Testament: Based on semantic domains, United Bible Societies, New York, NY.

Malphurs, A., 2007, A new kind of Church: Understanding models of ministry for the 21st Century, Baker Books, Grand Rapids, MI.

McLaren, B.D., [1998] 2000, The church on the other side: Doing ministry in the postmodern matrix, Zondervan, Grand Rapids, MI. (The 1998 publication was titled Reinventing your church.)

McPhee, A. 2006, 'Authentic witness, authentic evangelism, authentic church', in J.R. Krabill, W. Sawatsky \& C.E. Van Engen (eds.), Evangelical, ecumenical, and anabaptist missiologies in conversation: Essays in honor of Wilbert R. Shenk, pp. 130-139, Orbis, Maryknoll, NY.

Nel, M., 1994, Gemeentebou, Orion, Pretoria.

Nel, M., 1997-1998, 'Service evangelism: A style where theology and methodology meets', International Journal for Evangelism in Theological Education 13, 31-42.

Nel, M., 2000, Youth Ministry: An inclusive congregational approach, Malan Nel and Design Books, Pretoria.

Nel, M., 2002, "Serving them back": Youth evangelism in a secular and postmodern world', Journal of Youth and Theology 1(1), 65-87. http://dx.doi. org/10.1163/24055093-90000090

Nel, M., 2003, 'Youth Ministry: The challenge of individuation', Practical Theology in South Africa, 18(1), 151-196.

Nel, M., 2004, Who are we? Understanding and finding identity in the local church, Malan Nel, Pretoria.
Nel, M., 2007, 'Responsible evangelism in the presence of God: A theological reflection', Practical Theology in South Africa 22(1), 98-117.

Nel, M., 2009, 'Inviting and initiating youth into a life of discipleship', Verbum et Ecclesia 30(2), Art. \#344, 11 pages. http://dx.doi.org/10.4102/ve.v30i2.344

$\mathrm{Nel}, \mathrm{M} ., 2015$, Identity driven Churches: Who are we and where are we going? BibleMedia, Wellington.

Nelson, B. \& Jones, T.P., 2011, 'Introduction: The problem with family ministry,' in R. Stinson \& T.P. Jones (eds.), Trained in the fear of God. Family ministry in theological, historical, and practical perspective, pp. 13-29, Kregel Publications, Grand Rapids, Ml. http://dx.doi.org/10.1021/bk-2011-1064.ch001

Ogden, G., 1998, Discipleship essentials: A Guide to building your life in Christ, InterVarsity Press, Downers Grove, IL.

Ogden, G., 2003, Transforming discipleship: Making disciples a few at a time, InterVarsity, Downers Grove, IL.

Osmer, R.R., 1990, A teachable spirit: Recovering the teaching office in the church, Westminster John Knox, Louisville, KY.

Osmer, R.R., 1996, A teachable spirit: Recovering the teaching office in the Church, Westminster/John Knox, Louisville, KY.

Osmer, R.R., 2008, Practical theology: An introduction, Eerdmans, Grand Rapids, MI.

Osmer, R.R., 2012, 'Formation in the missional Church: Building deep connections between ministries of Upbuilding and Sending', in D.J. Zscheile (ed.), Cultivating sent communities: Missional spiritual formation, pp. 29-55, Eerdsmans, Grand Rapids, MI.

Ott, C. \& Wilson, G., 2011, Global church planting: Biblical principles and best practices for multiplication, Baker Academic, Grand Rapids, MI.

Quinn, R.E., 1996, Deep change: Discovering the leader within, Jossey-Bass, San Francisco, CA.

Putman, R.D., 2000, Bowling alone: The collapse and revival of American community, Simon \& Schuster, New York, NY.

Rengstorf, K.H., 1967, s.v. 'Mantanou', in G. Kittel, Theological dictionary on the new testament, transl. G.W. Bromiley, Eerdmans, Grand Rapids, MI, vol. 4, pp. 390-461.

Rothnagel, M., Schlag, T. \& Schweitzer, F. (eds.), 2014, Basics of religious education, Vandenhoeck \& Ruprecht, Göttingen.

Root, A., 2007, Revisiting relational youth ministry: From a strategy of influence to a theology of incarnation, InterVarsity Press, Downers Grove, IL.

Schlatter, A., [1933] 1963, Der Evangelist Matthaüs: Seine Sprache, sein Ziel, seine Selbständigkeit: Eine Kommentar zum ersten Evangelium, 6. Aufl., Calwer Verlag, Stuttgart.

Seibel, C.L. \& Nel, M., 2010, 'Generation X, intergenerational justice and the renewal of the traditioning process', HTS Teologiese Studies/Theological Studies 66(2), Art. \#876, 7 pages. http://dx.doi.org10.4102/hts.v66i2.876

Sjogren, S., 1993, Conspiracy of kindness, Vine Books, Ann Arbor, MI.

Sjogren, S., 2002, The perfectly imperfect Church: Redefining the "Ideal" Church, Flagship Church Resources, Loveland, CO.

Smit, D., 2014, Wat sien ons in die spieël?, Kindle edn., Lux Verbi, Kaapstad.

Stoppels, S., 2013, Oefenruimte. Gemeente en Parochie als gemeenschap van leerlingen, Boekencentrum, Zoetermeer.

Tillich, P., 1948, The protestant era, University of Chicago Press, Chicago, IL.

Trilling, W., 1969, 'Die Auferstehung Jesu: Anfang der neuen Weltzeit (Mt 28:1-8)', in W. Trilling (Hrsg.), Christusverkündigung in den synoptischen Evangelien: Beispiele gattungsgemässer Auslegung, Kösel Verlag, München.

Van Aarde, A.G., 2006, 'Hoe om in te kom en hoe om binne te bly - die 'groot sendingopdrag' aan die kerk vandag volgens Matteus 28:16-20', HTS Teologiese Studies/Theological Studies 62(1), 103-122. http://dx.doi.org/10.4102/hts. v62i1.345

Weber, S.M., 2014, 'Faith formation of young people in an Evangelical context: An empirical and theoretical study', DTh dissertation, Dept. of Practical Theology, University of Stellenbosch.

Willard, D., 1998, The divine conspiracy: Rediscovering our hidden life in God, Harper, San Francisco, CA.

Willard, D., 2006, The great omission: Reclaiming Jesus' essential teachings on discipleship, Harperone, San Francisco, CA.

Wilson, C., 1979, With Christ in the school of disciple building, Zondervan, Grand Rapids, MI.

Wolsheimer, J., 2012, Tegen de draad. Wat nou, crisis? Christus!, Ark Media, Amsterdam. 